\title{
Financial System Structure and Change - 1986-2005 Evidence from the OECD Countries
}

\author{
Angelos A. Antzoulatos \\ University of Piraeus \\ John Thanopoulos \\ University of Piraeus \\ Chris Tsoumas \\ University of Piraeus
}

\begin{abstract}
In this paper, we use sixteen financial indices from the World Bank's Financial Development and Structure database, to classify the OECD countries, according to their financial system structure, in five relatively homogenous clusters for the 1996-2005 period. We also examine the changes in their financial systems for the 1986-2005 period. Our analysis is based on the 'agglomerative method', a form of hierarchical clustering that uses Ward's methodology, to identify relatively homogenous groups of countries. The findings are surprising, yet reasonable. After two decades of deregulation, liberalization and globalization, the financial systems of the OECD countries not only differ in ways challenging the perceived wisdom that classifies them along the bank-based vs. capital-market-based norms, but additionally do not seem to converge to the second norm as is widely believed. These results warn against oversimplifications regarding financial system

\footnotetext{
*Corresponding address: Angelos A. Antzoulatos: Dep. of Banking \& Finance, University of Piraeus, 80 Karaoli \& Dimitriou street, Piraeus 18534, Greece, Tel: (++30210) 414-2185, e-mail: antzoul@unipi.gr, John Thanopoulos: Dep. of Business Administration, University of Piraeus, Tel: (++30210) 414-2256, e-mail: jt@unipi.gr, Corresponding author: Chris Tsoumas: Dep. of Banking \& Finance, University of Piraeus, Tel: (++30210) 414-2155, e-mail: ctsoum@unipi.gr.

(2008-Center for International Economics, Sejong Institution, Sejong University, All Rights Reserved.
} 
structure and the uncritical acceptance of policy recommendations based on them.

- JEL Classification: G10, G20

- Key Words: financial system structure, bank-based, capital-market-based, convergence, cluster analysis, OECD

\section{Introduction}

Constant change is one of the few certainties characterizing the financial system world-wide. As such, it has profound implications on the ways the world operates, the policy-makers' decision-making and the academic pronouncements. Essentially, the financial systems all over the world mutate constantly, creating in the process new financial status quos that need to sensitize business-people and regulators of the impending financial-system changes. Yet, these new status quos still surround the old distinction between capital-market-based and bank-based financial systems in which the primary sources of business financing respectively are capital markets and financial intermediaries.

The speed of change accelerated during the last twenty-five years, or so, driven by a worldwide wave of financial liberalization that has tilted the balance towards the capital-market norm, the revolution in information technology and globalization. Another driving force, though less acknowledged, was the enormous and rapidly growing literature that analyzed, among other themes, the relative merits of the two systems, their defining characteristics, the institutional infrastructure needed to support each, and ways to measure convergence.

In this paper, we study the trends of the financial systems in the OECD countries over the past twenty years, when the aforementioned drivers were operating at full throttle, and present their current status quo as clusters of gravitating financial activity. To do so, we use the World Bank's Financial Development and Structure database and a methodology that capitalizes on factor, discriminant and cluster analyses. The data matrix used focuses on sixteen primary financial indices during the 1986-2005 period. We focused on this matrix not only because of data recency and sample-country financial importance, but also because of data global standardization, availability, compatibility and comparability. 


\section{Literature Search and Initial Methodology Concerns}

Conceptually, our research approach has been used in the past along a unidimensional space, with polar cases the widely-perceived as archetypal capitalmarket and bank-based financial systems. The following graph, adapted from Allen and Gale (2001, p.22), is a prime example of such a mapping for the (until now) big five industrial countries, namely, U.S.A., U.K., Japan, France and Germany.

This mapping is primarily based on the structure of financial systems, the tradeoffs they attain in carrying out their main functions and the supporting institutional infrastructure. As a reminder, the main functions of the financial system can be summed up as a) transferring funds from those having a surplus, usually households, to those having a deficit, among them firms with -presumably-good investment projects; and b) providing the former fair and commensurate for the risks they assume returns.

The "structure" pertains to the main players and segments of the financial system: Households, firms, institutional investors and governments are among the former, and banks, other financial intermediaries (insurance companies, finance companies), and capital markets (bond and stock markets) among the latter. Briefly $^{1}$, in the ideal bank-based system, banks are more important than the (relatively under-developed) capital markets, and, accordingly, household financial assets are mainly in the form of claims on banks and insurance companies. As for the firms, most are not listed in a stock exchange, while for those listed there usually exist a few controlling shareholders. Consequently, institutional investors, such as, insurance firms and pension funds, play a minor role. Conversely, in the ideal capital-market-based system, capital markets are very developed, household financial assets are mainly in the form of stocks and bonds, shares are widely dispersed with no controlling shareholders, and institutional investors play a major role.

Figure 1. Mapping the Financial Systems

\begin{tabular}{ccccc} 
Market-based & & & & Bank-based \\
\hline U.S.A. & U.K. & Japan & France & Germany
\end{tabular}

Source: Adapted from Allen and Gale (2001, p. 22).

This discussion is based mainly on Allen and Gale (2001) and Byrne and Davis (2002). 
The "trade-offs" pertain to the exchanges between competition vs. insurance, public information vs. private information, external control of companies vs. autonomy in their actions, efficiency vs. stability. Note that these characteristics are mostly descriptive and qualitative. Furthermore, the first part of each exchange is associated with capital-market-based systems, while the second with bank-based ones.

To begin with, market-based systems are more competitive. They also offer better returns to suppliers and better terms to users of funds, by cutting down the intermediaries and their associated costs. However, the suppliers of funds face higher risk for they may have to liquidate their stocks and bonds when prices are low. In contrast, in bank-based systems, households attain better insurance through the well-diversified bank portfolios. Because of the sheer size of funds they can mobilize, banks can diversify their assets and essentially eliminate idiosyncratic firm risk, something households cannot do on their own with their limited financial resources. Households, instead, can invest in a few companies, thus remaining exposed to both idiosyncratic and market/macroeconomic risk.

In addition, in bank-based systems, firms develop long-run relationships with the banks they rely upon for external financing. In this way, informational asymmetries between the two are reduced. Banks, in general, have more information about the firms than is publicly available. And the need for more public information, which is crucial for the assessment of firms' prospects and, hence, for giving them the external funds they need in order to realize these prospects, is lower than in capitalmarket-based systems. Furthermore, in bank-based systems, banks monitor firm performance and exercise external control. In reality, though, firm managers have a lot of autonomy in their decision-making, for banks intervene only in extreme cases when firms are unable to service their loans, which autonomy managers do not always use in the shareholders best interest. In capital-market based systems, corporate control is exercised via the market mechanisms, usually hostile takeovers. Last, but not least, in a market-based system, with un-concentrated and competitive banking segment, efficiency may be higher but so is the potential for financial fragility.

As for the institutional infrastructure, the above indicate that capital-marketbased systems require better investor protection than bank-based systems. This, in turn, requires both rules and enforcement; i.e., laws and regulations against expropriation by insiders, both managers and controlling shareholders, and an efficient legal system that enforces them. 
Indeed, Common Law countries, which are commonly associated with the market-based paradigm, have stronger investor protection than French-Civil-Law and German \& Scandinavian-Civil-Law countries, which are commonly associated with the bank-based paradigm (La Porta et al., 1997 and 1998). In addition, ownership concentration is lower in countries with stronger investor protection ( $\mathrm{La}$ Porta et al., 1999). Not surprisingly, the existing evidence points to higher firm valuation in countries with better protection of minority shareholders (La Porta et al., 2002).

But financial systems, as this derives from the previous discussion and is widely acknowledged, are too complex to be readily reduced to a uni-dimensional space, bank-based vs. capital-market-based systems, though for the lack of better alternatives so far such a space is used. In other words, it is rather unlikely that the aforementioned trade-offs point in each and every country to the same direction, and only their intensity varies. We revisited, therefore, the existing literature in order to capitalize on the processes and conclusions of previous studies concerning processes, methodologies and financial trends word-wide.

During our research we discovered that relevant empirical studies are rare. In a prominent example, Byrne and Davis (2002) compare household and firm balance sheets in France, Germany, Italy and the U.K.. The following passage from their study is indicative of both the mapping used so far, and of the difficulty of fitting the great variety of financial systems around the world into such a uni-dimensional mold.

"The U.K. is commonly viewed as having a 'market oriented' financial system, in contrast to other European countries which are seen as 'bank dominated'. In the light of this supposition, ${ }^{2}$ we investigate sectoral balance sheet data for evidence of differences in financial system structures between the UK and other major EU countries. It is found that the UK has much in common with Continental countries, in particular France, and they are themselves markedly heterogeneous. There is also some evidence of convergence towards a more market-oriented financial system, even in the most bank-dominated economy, Germany."

Their conclusions are also echoed in a more detailed study that followed (Byrne and Davis, 2003).

Then, we visited the World Bank's Financial Development and Structure database in order to get some initial "feel" of the available data on a worldwide

\footnotetext{
${ }^{2}$ Emphasis added.
} 
basis and for practically all the years the data were available. The lack of data led us to reduce the large data matrix before we run initial factor and discriminant analyses.

In order to get a multi-dimensional "feel" of the data, and focusing on the values of eigenvectors, we decided to use a clustering approach to a) group the financial systems of the OECD countries, and b) identify the channels of their change, based on the systems' observed quantifiable characteristics. The relevant indices, described in Section 3, provide consistent measures of financial development and structure across different countries and, for the time being, represent the best one can hope for regarding such measures. By design, therefore, we examine the similarity-or dissimilarity-of financial system development and structure, as well as of change, by looking at the level of development and changes thereof in each segment of the financial system.

Our approach, while similar in spirit with that of Byrne and Davis (2002, 2003), is more comprehensive in country coverage and more robust in a statistical sense: It covers the OECD area, and compares the sample countries across several dimensions-indices simultaneously. Pertaining to the latter, we employed the 'agglomerative method', a form of hierarchical clustering that uses Ward's method (Kaufman and Rousseeuw, 1990, SPSS 13.0 Base User's Guide), to identify relatively homogenous groups of countries based on sixteen indices. This method, essentially, allows for a multi-dimensional comparison of financial system structure and change, without the restriction that all indices for the countries in each group are of similar magnitude or point to the same direction. Differences in some indices do not in principle preclude similarity in outcomes.

In more detail, hierarchical cluster analysis groups data in $\mathrm{k}$ clusters, where $\mathrm{k}$ takes all integer values in the $[1, n]$ space in one run and $n$ is the number of objects (in our case, the countries). This method is less computationally intensive and produces more transparent results than the partitioning method where $k$ is fixed and chosen by the user. Its main disadvantage stems from the fact that once an erroneous decision is made about the merge - or split - of a cluster as $k$ spans the $[1, n]$ space, this cannot be amended in any subsequent step. Depending on whether $k$ increases from 1 to $n$ or vice versa, hierarchical cluster analysis differentiates into the 'divisible' and the 'agglomerative' approach respectively. However, the divisible method is rarely used because of its larger computational need.

In the agglomerative hierarchical clustering approach, a similarity - or 
dissimilarity - measure must be defined according to which two clusters merge to form a bigger one. Different definitions of this measure have been used, while their relative strengths and weaknesses depend mainly on the nature of the data. Here, we employ the widely used Ward's method which is designed to minimize variance within clusters.

Specifically, the similarity measure between clusters $R$ and $Q$ is defined as the square root of the Euclidean distance between their centroids, i.e., their center of gravity. It is given by:

$$
d^{2}(R, Q)=\frac{2|R||Q|}{|R|+|Q|}\|\bar{x}(R)-\bar{x}(Q)\|^{2}
$$

where $|R|$ and $|Q|$ denote the number of objects in these clusters, while $\bar{x}(R)$ and $\bar{x}(Q)$ are the centroids of the two clusters. The centroids are defined as:

$$
\bar{x}(R)=\left(\overline{x_{1}}(R), \overline{x_{2}}(R), \cdots, \overline{x_{p}}(R)\right)
$$

In this equation $\quad \bar{x}_{f}(R)=\frac{1}{|R|} \sum_{i \in R} x_{i f} \quad$ with $f=1, \cdots, p$, where $\mathrm{p}$ stands for the number of variables used for each country and $x_{i f}$ denotes the value of the $f$ financial development index for country $i$ which belongs to cluster $R$.

Additionally, the Error Sum of Squares (ESS) is computed for each cluster, defined as the sum of the squared Euclidean distances between all the countries in the cluster and its centroid:

$$
\operatorname{ESS}(R)=\sum_{i \in R}\left\|x_{i}-\bar{x}(R)\right\|^{2}
$$

The $\operatorname{ESS}(R)$ can be interpreted as a measure of the 'tightness' of cluster $R$. Accordingly, ESS is the sum of the ESS(R) of all clusters. According to Ward's method, clusters merge so as the smallest possible increase in the ESS occurs. Thus, this method leads to merging those clusters with the minimum distance $d(R, Q)$ between them. The dendrogram visualizes the procedure of cluster merging, showing in the horizontal axis the rescaled dissimilarity measure based on equation (1).

We do recognize the limitations of both the quantitative technique (clustering) and the available indices regarding their ability to capture the subtle and not-sosubtle differences among the various financial systems, especially in light of the fact that several of them, like the quality of the institutional setting, are hard to quantify. Nevertheless, we believe that this analysis has the potential to shed some new light on the issues under examination. 
Our findings greatly support this belief. In its support, even though the (numerous) drivers of change over the past twenty five years have been more-orless the same across the sample countries, ${ }^{3}$ each country followed its own financial liberalization pace and path (Williamson and Mahar, 1998, Edey and Hviding, 1995) and, thus, reached different levels of financial development in a variety of financial system structures. The outcome was also influenced by such factors as the legal infrastructure, political tradition, and economic and financial history (Fohlin, 2000, Rajan and Zingales, 2003).

Our findings suggest that the mapping of financial systems along the aforementioned uni-dimensional space jeopardizes the power of testing and reduces the validity of the conclusions. It may also lead to questionable policy recommendations.

Put it in a different way, it is unlikely that there is a unique mapping from the overall economic setting to the structure of the financial system. The setting includes the structure of the economy and its development level, the players, the regulatory and supervisory infrastructure and its quality. The same applies to institutional changes, for two countries, which have similar financial systems and implement the same reforms, may end up with different financial systems.

Essentially, there may be many different ways of efficiently carrying out the functions of the financial system and, thus, many different efficient financial systems, in which case the logical underpinnings of the presumed financial system convergence are undermined. Indeed, history, entrenched interests, economic structure, among many other factors, plays a role (Rajan and Zingales, 2003).

\section{Data Description}

The data comes from the World Bank's Financial Development and Structure database, available at http://econ.worldbank.org. This database contains a large set of indices, which measure the size, activity and efficiency of financial

\footnotetext{
${ }^{3}$ These were major institutional reforms and market-driven developments. Prominent among the former were financial liberalization, which decreased the degree of financial repression, increased competition in domestic financial markets and led to a largely liberalized financial system; pension reform that diminished expectations of pension benefits, and the enactment of laws for minority-shareholder protection. As for the market-driven developments, they include the integration of world financial markets, the revolution in informational technology (Allen and Santomero, 2001, Mishkin and Strahan, 1999), that lowered transaction costs and facilitated competition, information dissemination (thus reducing the problem of asymmetric information) and capital-market participation and trading.
} 
intermediaries (banks, insurance companies, finance companies, ${ }^{\cdots}$.) and the stock and bond markets, in a consistent across countries way, on a yearly basis from 1960 to 2005 (Beck et al., 2000).

We restrict the analysis to the OECD countries minus Luxemburg, mainly because of their economic significance. Luxemburg is effectively a statistical outlier, a special case: a small country with a disproportionately big financial system that caters mainly to foreigners. The sample, therefore, includes Australia, Austria, Belgium, Canada, the Czech Republic, Denmark, Finland, France, Germany, Greece, Hungary, Iceland, Ireland, Italy, Japan, Korea, Mexico, the Netherlands, New Zealand, Norway, Poland, Portugal, the Slovak Republic, Spain, Sweden, Switzerland, Turkey, the United Kingdom and the United States.

Due to data availability considerations, together with the need for a balanced dataset across the various segments of the financial system, we further restrict the analysis to the sixteen indices shown in Table 1 for the period 1996-2005, and to thirteen indices for the period 1986-2005. Nevertheless, these indices cover adequately the major segments of the financial system, namely, financial intermediaries (banks and other financial intermediaries), and the stock and bond markets. In addition, due to their scaling, usually with the gross domestic product (GDP), the different economic size of the sample countries does not drive the results, nor does it affect their interpretation.

From these indices, V1 to V6 refer to the size and activity of the financial intermediaries segment. Specifically, V1 refers to the role of the central bank in the financial intermediation process-generally a high V1 indicates a liberalized financial system in which the central bank plays a minor role in the intermediation process; V2 refers to overall liquidity in the economy-a variable indicative of the level of financial intermediation; V3 to the size of the traditional banking segment; V4 and V5 to private credit by banks and other financial institutions, allowing a comparison of their relative strength in providing credit to the private sector and V6 to deposits in banks and other financial institutions.

V7 to V9 refer to the efficiency and structure of the banking segment. In greater detail, V7 refers to banks' overhead costs, with a low value indicating an efficient banking system; V8 to banks' net interest margin, a low value of which is usually associated with a competitive banking system; and V9 to bank concentration.

The remaining seven indices pertain to the other major segments of the financial system. Specifically, V10 and V11 refer to the development of the insurance industry; V12, V13 and V14 to the size, activity and efficiency of the stock market 
-the last two being measured by liquidity and turnover ratio respectively (Beck et al., 2000); and V15 and V16 to the size of the private and public bond markets.

We explore two issues: a) the structure of the financial system of the sample countries for the period 1996-2005 and b) the main forces behind the changes that occurred over the past twenty years. For the first, we apply hierarchical cluster analysis to the ten year average (mean) for each index for each country. Using the ten year averages limits the noise from cyclical influences on these indices. For the second, we apply the same analysis on the differences between the averages of the 1996-2005 and 1986-1995 periods of the relevant indices for each country.

Before applying the analysis, all indices have been re-scaled by variables, that is, for each variable across countries, to the $[0,1]$ space, in order to avoid any 'overweighting' from variables that exceeded 1 , relative to these that are below this figure. Nevertheless, the results were qualitatively the same without this re-scaling.

Hierarchical cluster analysis does not produce a unique number of clusters. Given, however, the difficulty of extracting useful conclusions from a large number of clusters, we directed our efforts to finding the best trade off between relatively homogenous and sufficiently different between them clusters, on the one hand, and a small number of clusters, on the other. The results indicate that five clusters represent the best trade off for both analyses.

\section{Results}

At a first glance, the results are unexpected; on closer inspection reasonable, quite interesting and very insightful.

Briefly, pertaining to the financial system development and structure for the period 1996-2005, we identified five clusters of countries:

comprising of the Czech Republic, Hungary, Mexico, Poland, the Slovak Republic and Turkey, the group with the least developed -in all segments-and least competitive financial system.

Two, Belgium, Greece, Italy and Japan, which have a bank-centered financial system.

Three, Australia, Austria, Canada, Denmark, Finland, France, Germany, Iceland, Ireland, New Zealand, Norway, Portugal, Spain and Sweden, countries which represent the 'middle group' in terms of development of all segments of the financial system.

Four, the Netherlands, Switzerland and the U. K., which have well-developed 
Table 1. Financial Development and Structure Indices

\begin{tabular}{|c|c|c|c|c|}
\hline & \multirow{2}{*}{ Index } & \multirow{2}{*}{ Definition } & \multicolumn{2}{|c|}{ Availability } \\
\hline & & & $1986-2005$ & 1996-2005 \\
\hline V1 & $\begin{array}{l}\text { Deposit Money Bank vs. Central Bank } \\
\text { Assets }\end{array}$ & $\begin{array}{l}\text { Ratio of deposit money bank claims on domestic non-financial real } \\
\text { sector to the sum of deposit money bank and Central Bank claims on } \\
\text { domestic non-financial real sector }\end{array}$ & & \\
\hline $\mathrm{V} 2$ & Liquid Liabilities to GDP & Liquid liabilities to GDP & & \\
\hline V3 & Deposit Money Bank Assets to GDP & $\begin{array}{l}\text { Claims on domestic real non-financial sector by deposit money banks } \\
\text { as a share of GDP }\end{array}$ & & \\
\hline V5 & $\begin{array}{l}\text { Private Credit by Deposit Money Banks and } \\
\text { Other Financial Institutions to GDP }\end{array}$ & $\begin{array}{l}\text { Private credit by deposit money banks and other financial institutions } \\
\text { to GDP }\end{array}$ & & \\
\hline V6 & Financial System Deposits & $\begin{array}{l}\text { Demand, time and saving deposits in deposit money banks and other } \\
\text { financial institutions as a share of GDP }\end{array}$ & & \\
\hline V7 & Overhead Costs & Accounting value of a bank's overhead costs as a share of its total assets & & \\
\hline V8 & Net Interest Margin & $\begin{array}{l}\text { Accounting value of bank's net interest revenue as a share of its inter- } \\
\text { est-bearing (total earning) assets }\end{array}$ & & \\
\hline V9 & Concentration & $\begin{array}{l}\text { Assets of three largest banks as a share of assets of all commercial } \\
\text { banks in the system }\end{array}$ & & \\
\hline V10 & Life Insurance Penetration & Life insurance premium volume as a share of GDP & & \\
\hline V11 & Non-life Insurance Penetration & Non-life insurance premium volume as a share of GDP & & \\
\hline $\mathrm{V} 12$ & Stock Market Capitalization to GDP & Value of listed shares to GDP & & \\
\hline V13 & Stock Market Total Value Traded to GDP & Total shares traded on the stock market exchange to GDP. & & \\
\hline V14 & Stockmarket Turnover Ratio & $\begin{array}{l}\text { Ratio of the value of total shares traded and average real } \\
\text { market capitalization }\end{array}$ & & \\
\hline V15 & Private Bond Market Capitalization to GDP & $\begin{array}{l}\text { Private domestic debt securities issued by financial institutions and } \\
\text { corporations as a share of GDP }\end{array}$ & & \\
\hline V16 & Public Bond Market Capitalization to GDP & Public domestic debt securities issued by government as a share of GDP & & \\
\hline
\end{tabular}


both the banking and capital markets segments.

Five, Korea and the U.S., which have in some respects the most capital-market oriented systems.

As for the financial system changes for the period 1985-2006, the five clusters are:

One, comprising of Australia, Austria, Germany, Greece, Hungary and Mexico, in which both the financial intermediaries and the stock market segments developed but the latter about 50\% more than the former. In addition, both segments' development was about half than that of the full sample.

Two, Finland, France, Japan, Norway and Sweden, in which stock market development was roughly equal to that of the full sample average, while the banking system stagnated with its activity declining.

Three, Belgium, Switzerland and the U. K., in which the development of the banking segment was about sample average, while that of the stock market about twice that of the full sample.

Four, Canada, Denmark, Italy and Portugal, in which both the stock market and the banking segments developed in about the same degree. This degree was higher than the corresponding sample average for the banking segment, and lower than the corresponding sample average for the stock market.

Five, Korea, the Netherlands, Spain and the U.S., in which the activity of financial intermediaries and the efficiency of the stock market, together with the size of the private bond market, recorded their highest levels among all clusters.

The results are summarized by the dendrograms in Figures 1 and 2, and in Tables 2 to 5 . The dendrograms are the graphical representation of the cluster trees formed using hierarchical clustering.

In greater detail, Figure 1 summarizes the cluster analysis of the sample countries' financial system development and structure for the 1996-2005 period and Figure 2 the analysis of the changes there-off during the 1986-2005 period. Both figures have the same structure. The horizontal axis shows the rescaled dissimilarity measure used to assign each multi-dimensional observation to a country. The vertical axis shows the countries.

From the visual inspection of the two dendrograms we conclude that the best trade-off is attained with five clusters for both the development and structure of the financial systems of the sample countries and for their changes.

Tables 2 and 4 report descriptive statistics for the aforementioned two cluster analyses, while Tables 3 and 5 summarize the conclusions drawn from these statistics. Tables 2 and 4 have the same structure. The first and the second column 
show the clusters and the number of countries in each. The remaining columns show the mean (Panel A) and the coefficient of variation (Panel B) for each index for the clusters identified and for the full sample. For example, in Table 2, (the mean of) V1 is 0.911 for the six countries in cluster 1, 0.989 for those in cluster 4, and 0.958 for all sample countries. To make the reading of the tables easier, the figures driving the conclusions are highlighted.

\section{A. Financial System Development and Structure - 1996-2005}

Figure 2 indicates that a large number of clusters with relatively small levels of dissimilarity among countries can be formed using the ten-year means of the sixteen indices. From this graph we conclude that the best trade off is attained with five clusters. Any attempt to further reduce the number of clusters would result in groups of countries with very different financial systems, while any attempt to retain a larger number would result in thinly populated groups. In both cases, it would be very difficult to reach any useful conclusions.

As Table 2 documents, the coefficient of variation for essentially all sixteen indices is generally lower, often substantially so, in the thus formed clusters relative to that for the full sample, implying greater homogeneity within each cluster than in the full panel itself. Indicatively, the coefficient of variation of the deposit money bank assets to GDP (V3) ranges from 0.166 in cluster 4 to 0.250 in cluster 2, while it is 0.422 for the full sample. For the stock market capitalization to GDP (V12), the coefficient of variation ranges from 0.391 in cluster 1 to 0.454 in cluster 3, while it is 0.711 for the full sample.

Table 2 also presents the means of the indices for each cluster. These descriptive statistics are used to define the distinguishing characteristics of the financial system structure and development in each cluster. For ease of comparison, Table 3 summarizes the aforementioned characteristics.

The countries in cluster 1, namely, the Czech Republic, Hungary, Mexico, Poland, the Slovak Republic and Turkey, have the least developed and least competitive financial systems. Neither banks nor the stock market are developed, as indicated by the very low private credit (V5) and stock market capitalization (V12), respectively at 0.299 and 0.203 . Banks are highly inefficient, with overhead costs (V7) at 0.046 by far the biggest, yet they earn the highest net interest margin (V8), at 0.058 almost twice as high as the sample average. Perhaps compensating for the under-developed financial system, the central bank plays a significant role; 
Figure 2. Financial System Status - 1996-2005

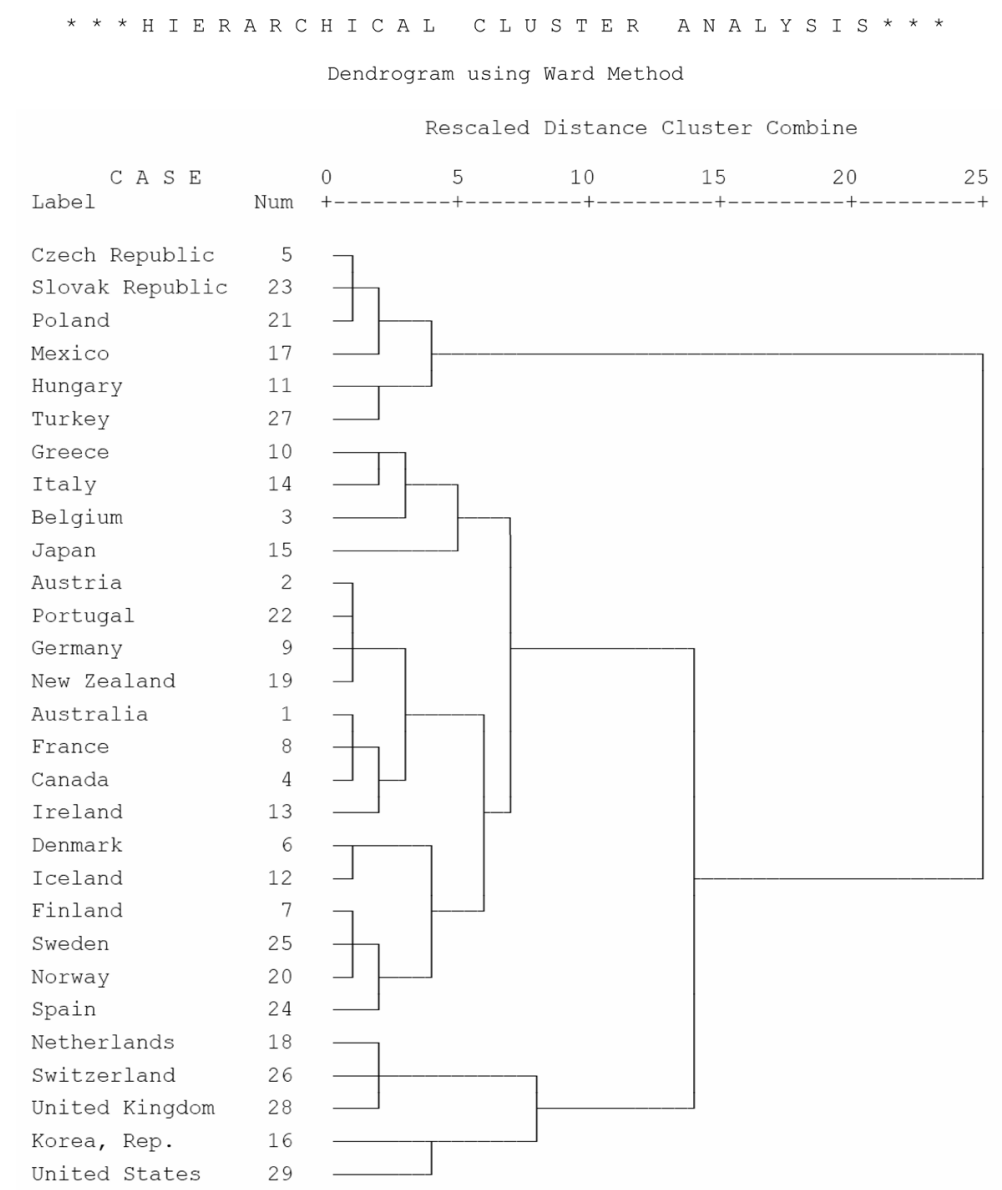

deposit money bank vs. central bank assets (V1), at 0.911, is the lowest. Other financial intermediaries and the private bond market are essentially non-existent, while life insurance penetration is extremely low.

The countries in cluster 2, namely, Belgium, Greece, Italy and Japan have a bank-centered financial system, in which the size of banks is more than $50 \%$ higher than the size of the stock market. Specifically, deposit money bank assets to GDP (V3) are 1.073, while stock market capitalization to GDP (V12) is 0.654. Other financial intermediaries are essentially non-existent since private credit by deposit money banks to GD (V4) is 0.769 , very close to private credit by both money banks and other financial institutions (V5) 0.824. Additionally, private credit by banks, a measure of banking segment's activity, is more than twice stock market liquidity (V13), which is 0.386 , the second lowest among all clusters and 
Table 2. Descriptive Statistics - Financial System Development and Structure, 1996-2005

\begin{tabular}{|c|c|c|c|c|c|c|c|c|c|c|c|c|c|c|c|c|c|}
\hline Cluster & Obs. & V1 & $\mathrm{V} 2$ & V3 & V4 & V5 & V6 & V7 & V8 & V9 & V10 & V11 & V12 & V13 & V14 & V15 & V16 \\
\hline \multicolumn{18}{|c|}{ Panel A. Means } \\
\hline 1 & 6 & 0.911 & 0.456 & 0.447 & 0.296 & 0.299 & 0.402 & 0.046 & 0.058 & 0.661 & 0.009 & 0.016 & 0.203 & 0.156 & 0.691 & 0.020 & 0.260 \\
\hline 2 & 4 & 0.925 & 1.018 & 1.073 & 0.769 & 0.824 & 0.857 & 0.028 & 0.024 & 0.648 & 0.046 & 0.024 & 0.654 & 0.386 & 0.617 & 0.322 & 0.918 \\
\hline 3 & 14 & 0.984 & 0.694 & 1.003 & 0.893 & 0.953 & 0.654 & 0.030 & 0.026 & 0.781 & 0.041 & 0.031 & 0.667 & 0.524 & 0.740 & 0.380 & 0.365 \\
\hline 4 & 3 & 0.989 & 1.197 & 1.614 & 1.499 & 1.587 & 1.199 & 0.036 & 0.020 & 0.646 & 0.075 & 0.045 & 1.666 & 1.470 & 0.908 & 0.355 & 0.343 \\
\hline 5 & 2 & 0.935 & 0.607 & 0.597 & 0.566 & 1.603 & 0.659 & 0.029 & 0.034 & 0.395 & 0.062 & 0.038 & 0.892 & 1.529 & 1.932 & 0.727 & 0.304 \\
\hline $\begin{array}{c}\text { Full } \\
\text { Panel }\end{array}$ & 29 & 0.958 & 0.735 & 0.933 & 0.792 & 0.910 & 0.687 & 0.034 & 0.032 & 0.697 & 0.040 & 0.029 & 0.688 & 0.596 & 0.812 & 0.319 & 0.413 \\
\hline \multicolumn{18}{|c|}{ Panel B. Coefficient of Variation } \\
\hline 1 & 6 & 0.106 & 0.319 & 0.239 & 0.426 & 0.407 & 0.316 & 0.334 & 0.677 & 0.096 & 0.408 & 0.318 & 0.391 & 0.998 & 0.641 & 1.234 & 0.355 \\
\hline 2 & 4 & 0.062 & 0.545 & 0.250 & 0.323 & 0.429 & 0.449 & 0.331 & 0.262 & 0.369 & 0.705 & 0.467 & 0.241 & 0.366 & 0.492 & 0.665 & 0.071 \\
\hline 3 & 14 & 0.015 & 0.251 & 0.230 & 0.208 & 0.149 & 0.246 & 0.303 & 0.248 & 0.202 & 0.576 & 0.239 & 0.454 & 0.636 & 0.478 & 0.854 & 0.373 \\
\hline 4 & 3 & 0.008 & 0.157 & 0.166 & 0.118 & 0.180 & 0.213 & 0.425 & 0.328 & 0.234 & 0.273 & 0.029 & 0.332 & 0.307 & 0.123 & 0.449 & 0.332 \\
\hline 5 & 2 & - & - & - & - & - & - & - & - & - & - & - & - & - & - & - & - \\
\hline $\begin{array}{c}\text { Full } \\
\text { Panel }\end{array}$ & 29 & 0.061 & 0.444 & 0.422 & 0.480 & 0.498 & 0.428 & 0.367 & 0.690 & 0.255 & 0.714 & 0.386 & 0.711 & 0.884 & 0.585 & 0.963 & 0.581 \\
\hline \multicolumn{18}{|c|}{$\begin{array}{l}\text { Notes: } \\
\text { 1. Sources: Financial Development and Structure database (World Bank), and authors' calculations. } \\
\text { 2. Obs.: Number of observations/countries. } \\
\text { 3. Variable definitions: see Table } 1 \text { and the main text. } \\
\text { 4. For cluster 5, which includes only two countries, the coefficient of variation is not calculated. }\end{array}$} \\
\hline
\end{tabular}


Table 3. Main Characteristics? Financial System Development and Structure, 1996-2005

Cluster Constituent countries

Czech Republic, Hungary,

1 Mexico, Poland, Slovak

Republic, Turkey

2 Belgium, Greece, Italy, Japan

Australia, Austria, Canada

Denmark, Finland, France,

3 Germany, Iceland, Ireland,

New Zealand, Norway, Portugal, Spain, Sweden

4 Netherlands, Switzerland,

United Kingdom

$5 \quad$ Korea, United States
This cluster includes the countries with the least developed and least competitive financial system. Neither banks nor the stock market are developed. Banks are highly inefficient, yet they earn the highest net interest margin. The central bank plays a bigger role than in the other clusters. Other financial intermediaries and the private bond market are essentially non-existent, while life insurance penetration is extremely low.

This is the most bank-oriented cluster. The size and activity of banks relative to GDP is more than 50\% higher than the size of the stock market. The banking sector is highly efficient, the insurance industry and the private bond market are not particularly developed, while the public bond market size relative to GDP is the biggest among all clusters.

This cluster is in the middle, with about average-relative to the full sample- indices. Private credit (to GDP) is about the same with stock market capitalization, other financial intermediaries play a minor role, while the banking system has the highest concentration.

Financial intermediaries play a major role, bigger than in Cluster 3, with the banks being dominant yet other financial intermediaries having a considerable share of private credit and deposits. Bank concentration is below average, and banks are very efficient and competitive. Net interest margin is the lowest among all clusters. The role of the central bank is very limited. The insurance industry, the stock market and the bond market are very developed as well, with this cluster having the highest insurance penetration and stock market capitalization.

In some respects, this is the most market-oriented cluster. Private credit is high, higher than stock market capitalization, since other financial intermediaries are more important than banks. Bank concentration is the lowest, yet net interest margin is the highest among the four clusters which contain the countries with the most advanced financial systems. In addition, the stock market is characterized by the greatest depth and liquidity, while the private bond market is the most developed. 
Table 4. Descriptive Statistics - Financial System Changes, 1986-2005

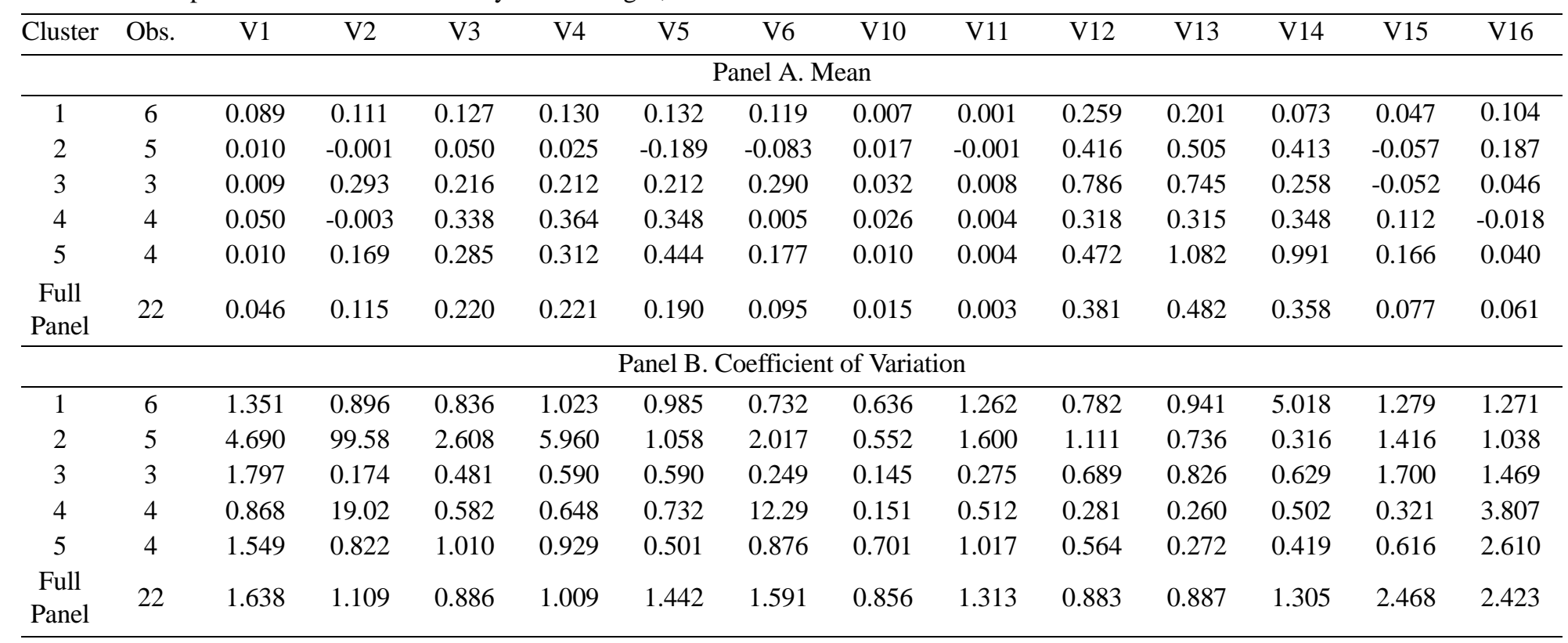

Notes:

1. Sources: Financial Development and Structure database (World Bank), and authors' calculations.

2. Obs.: Number of observations/countries.

3. Variable definitions: see Table 1 and the main text. 
Table 5. Main Characteristics - Financial System Changes, 1986-2005

\begin{tabular}{|c|c|c|}
\hline luster & Constituent countries & Characteristics \\
\hline 1 & $\begin{array}{l}\text { Australia, Austria, Germany, } \\
\text { Greece, Hungary, Mexico }\end{array}$ & $\begin{array}{l}\text { In this cluster the increase was modest in both the banking segment's size and in the stock market size } \\
\text { and liquidity. The increase in the stock market depth was the lowest among all clusters. }\end{array}$ \\
\hline 2 & $\begin{array}{l}\text { Finland, France, Japan, Nor- } \\
\text { way, Sweden }\end{array}$ & $\begin{array}{l}\text { This cluster includes countries with a, more or less, unchanged banking segment in terms of size and } \\
\text { activity, while it is the only one in which private credit by other financial intermediaries declined sub- } \\
\text { stantially. Stock market size and liquidity increased about average, while the public bond market had the } \\
\text { biggest increase among all clusters. }\end{array}$ \\
\hline 3 & $\begin{array}{l}\text { Belgium, Switzerland, United } \\
\text { Kingdom }\end{array}$ & $\begin{array}{l}\text { Liquid liabilities, financial system deposits, insurance penetration and stock market capitalization } \\
\text { recorded the biggest increase. The gain in the size and activity of banks, together with the average } \\
\text { change in the stock market depth was about average, while the increase in stock market liquidity was the } \\
\text { second biggest among clusters. }\end{array}$ \\
\hline 4 & $\begin{array}{l}\text { Canada, Denmark, Italy, Portu- } \\
\text { gal }\end{array}$ & $\begin{array}{l}\text { These countries experienced the biggest increase in the asset size and activity of their banking segment, } \\
\text { which, however was not followed by a corresponding increase in deposits, the latter being almost stable. } \\
\text { Life insurance penetration and private bond market size recorded the second biggest increase, while the } \\
\text { stock market size, liquidity and depth development was below average. }\end{array}$ \\
\hline 5 & $\begin{array}{l}\text { Korea, Netherlands, Spain, } \\
\text { United States }\end{array}$ & $\begin{array}{l}\text { This cluster includes countries with the biggest increase in other financial intermediaries' activity, stock } \\
\text { market characteristics and private bond market size. The size and activity of financial intermediaries, } \\
\text { and financial system deposits also increased above average. }\end{array}$ \\
\hline
\end{tabular}


exceeding only that of cluster 1. Stock market turnover ratio (V14), which is 0.617 , is the lowest, lower even than from the corresponding figure for cluster 1, which includes the least financially develop countries. However, the banking sector is very efficient, with the lowest overhead costs (V7) at 0.028 , and the second lowest net interest margin (V8) at 0.024 . The insurance industry and the private bond market are not particularly developed, with the values of the respective indices (V10, V11 and V15) ranging about the sample means. The public bond market instead (V16) is the most developed, at 0.918.

For cluster 3, with constituent countries Australia, Austria, Canada, Denmark, Finland, France, Germany, Iceland, Ireland, New Zealand, Norway, Portugal, Spain and Sweden, all indices are approximately equal to the sample means. Yet, in this "average" cluster, bank concentration (V9), at 0.781, is the highest.

In the countries in cluster 4, namely the Netherlands, Switzerland, and the U.K, financial intermediaries play a major role, with liquid liabilities (V2) at 1.197 and private credit by banks (V4) at 1.499, but the stock market is very developed as well, as indicated by the stock market capitalization to GDP (V12) at 1.666. All three figures are the highest for all clusters. Within the financial intermediaries segment, banks are dominant, yet other financial intermediaries have a significant share, as indicated by the means of V4 and V5-respectively at 1.499 and 1.587 Banks are also very competitive, as indicated by the lowest net interest margin (V8) at 0.020 , yet not so efficient, since overhead costs (V7) is at 0.036 , about the sample average. The insurance industry is very developed as well, with life insurance penetration (V10) at 0.075 by far the highest of all clusters, and non-life insurance penetration (V11) at 0.045 the highest as well. Last but not least, the bond market is not particularly developed.

In several respects, the countries in cluster 5, Korea and the U.S., have the most market-oriented financial system that is also characterized by the least concentrated yet very profitable banking segment. Private credit (V5) is high, at 1.603 is higher than stock market capitalization (V12) which is at 0.892 , yet credit by other financial intermediaries is as important as credit by banks - bank credit (V4) at 0.566 is about one third of total credit (V5) at 1.603. Also, despite that bank concentration (V9) at 0.395 is by far the lowest among all clusters, net interest margin (V8), at 0.034 , is the highest among the four clusters which contain the countries with the most advanced financial systems. In addition, the stock market is characterized by the greatest depth, with turnover ratio (V14) at 1.932 - by far the highest in the sample. Also, the private bond market capitalization (V15) at 0.727 
is by far the highest. Worth also noting, deposits are not the main source of funds for these institutions, as the relatively small financial system deposits (V6), at 0.659 , indicate.

\section{B. Financial System Changes - 1986-2005}

Due to data availability restrictions for the 1986-1995 period, the Czech Republic, Iceland, Ireland, New Zealand, Poland, the Slovak Republic and Turkey are dropped from the sample. In addition, as mentioned above, thirteen indices are used. The three excluded indices are overhead costs, net interest margin and concentration.

As it turns out from Figure 3, the collective impact of the numerous drivers of change can be summarized in five relatively homogenous clusters. Analogously with the analysis of the financial system development and structure, Table 4 reports the distinguishing characteristics, with the statistics driving the conclusions highlighted, and Table 5 summarizes the conclusions

In greater detail, the coefficient of variation within the five clusters is generally lower, in absolute values, than that of the full sample for the majority of the indices used. For two indices, in particular, it is substantially lower in all five clusters. Specifically, the coefficient of variation of private credit by deposit money banks and other financial intermediaries to GDP (V5) ranges from 0.501 to 1.058 in the five clusters, while it is 1.442 for the full sample. Also, for private bond market capitalization to GDP (V15) it ranges from 0.321 to 1.416 , while in the full sample it is 2.468 .

As for the means, in cluster 1, with constituent countries Australia, Austria, Germany, Greece, Hungary and Mexico, all financial development variables increased, although, the vast majority of them below the relevant full sample means. Above sample averages increases exhibited the deposit money bank assets vs. central bank assets (V1) at 0.089 vs. 0.046 in the full sample, financial system deposits (V6) at 0.119 vs. 0.095 , and public bond market capitalization (V16) at 0.104 vs. 0.061 . The increase in the stock market turnover ratio (V14) was 0.073 , the lower in all clusters. Indicating a slight shift of these countries' financial system towards the market-based norm, the increases were bigger for stock market capitalization and stock market value traded to GDP than for most banking segment's variables. The respective figures are 0.259 and 0.201 (V12 and V13) vs. $0.111,0.127$ and 0.130 (V2, V3 and V4). 
Figure 3. Financial System Changes-1986-2005

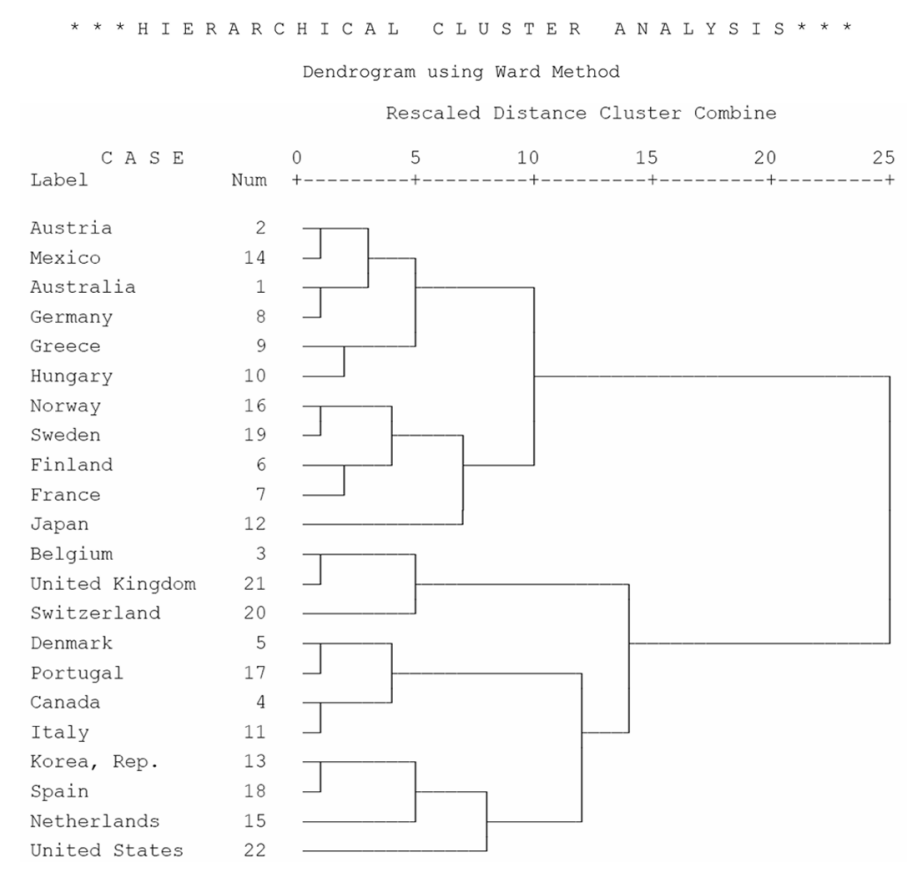

For the countries in cluster 2, namely, Finland, France, Japan, Norway and Sweden, the stock market developed more than in cluster 1 in terms of size (V12) and liquidity (V13), and much more in terms of depth (V14). However, their development did not exceed by much the average means. Specifically, V12, V13 and V14 were at $0.416,0.505$ and 0.413 respectively for the countries in this cluster and $0.381,0.482$ and 0.358 for the full sample. Additionally, the increase in these variables was not accompanied by any significant increase in the financial intermediaries segment. On the contrary, private credit (V5) recorded a substantial decrease, at -0.189 , the only one among all clusters, while financial system deposits (V6) and private bond market size (V15) decreased as well, although to a lesser extent, at -0.083 and -0.057 respectively.

In cluster 3, with constituent countries Belgium, Switzerland and the U.K., financial intermediaries' size and activity measures experienced an average increase, comparable to that of the full sample, while the insurance industry (V10 and V11) and stock market capitalization (V12) recorded the bigger increase among all clusters, at $0.032,0.008$ and 0.786 respectively. Stock market liquidity (V13) also increased substantially by 0.745 . The private and public bond markets (V15 and V16) followed different paths. The first decreased slightly, the second 
increased, at -0.052 and 0.046 respectively.

In cluster 4, Canada, Denmark, Italy and Portugal experienced a 'balanced' increase in the financial intermediaries and the stock market's segments, with all the relevant measures having about the same magnitude. The former segment however developed more, while the latter less than that of the full sample.

Finally, the countries in cluster 5, namely, Korea, Netherlands, Spain and the U.S. are characterized by the biggest increases in private credit (V5) at 0.444 , stock market liquidity and turnover ratio (V13 and V14) at 1.082 and 0.991 respectively, and private bond market size (V15) at 0.166 .

Further highlighting the idea that different structures may carry out the functions of the financial system equally efficiently, the EU-member countries, which over the past twenty years implemented the same EU directives, not only have different structures, but additionally have followed different development paths. Indicatively, in Germany and Greece (cluster 1), financial system changes were modest in both the financial intermediaries and the stock market segments. In Netherlands and Spain (cluster 5), they were more pronounced in the capital markets segment.

Finally, a battery of sensitivity checks was conducted, for both cluster analyses. Specifically, we used different rescaling techniques and fewer financial intermediaries' segment variables. We also shifted the period under examination for two years back. The results were essentially the same.

\section{Discussion and Implications}

The unexpected at a first glance, but reasonable on closer inspection, results not only challenge the perceived wisdom on several fronts, but additionally offer new insights about the structure of financial systems and the forces driving changes in them. More importantly, they warn against simplifications and the uncritical acceptance of claims about the convergence of financial systems and of policy recommendations based on them.

To begin with, the statistics in Table 2 indicate that the financial systems of the O.E.C.D. countries do differ, even after twenty-five years of relentless deregulation, liberalization and globalization. Yet, they can be grouped into five relatively homogenous clusters.

These clusters however, do not readily conform to the capital market based vs. the bank based norms. Simply put, and with the possible exception of the one that includes the relatively less developed countries, these clusters contain several 
surprises. For example, the Anglo-Saxon countries, namely, Australia, New Zealand, the U.K. and the U.S., which, as indicated by the literature review in section 2, are widely thought to have capital market-based systems, are in three different clusters. So, the distinction between the Anglo-Saxon countries vs. the rest of the world is to some extend, and per our analysis, negated.

Also, Korea and the United States are in the same cluster, in fact, they form a cluster of their own. Surprising? Hardly so, for these two countries have very developed and active other financial intermediaries and stock market segments, in spite of their contextually differing cultures.

Perhaps, the biggest surprise, which does not bode well with the notion that financial systems are likely to converge to the capital-market-based norm, is that countries that differ a lot in terms of economic development, social systems, cultures and institutions, have similar financial systems: They are in the same cluster.

Casting further doubt on this notion, financial systems change, but not necessarily towards the same direction nor at the same pace. As the dendogram of systemic changes indicates, in some countries the biggest changes took place not only in the capital markets segment but in the financial intermediaries segment as well. Yet, at least some of them, Belgium and Denmark, have both the institutional setting and the quality of institutions to support a capital-market-based financial system.

One implication of the above is that any comparison of financial systems should be multi-dimensional. Consider for example, the countries in clusters 4 and 5 in the first analysis (Table 2). The countries in both clusters have about the same private credit by banks and other financial intermediaries (V5), life insurance penetration (V10) and stock market total value traded (V13). Yet, the countries in cluster 4 have higher private credit by banks (V4) and stock market capitalization (V12), while the countries in cluster 5 have higher stock market turnover ratio (V14). Which of the two is the more market-oriented one? Recall that cluster 5 includes the U.S., the country with the widely accepted as the archetypal market-based system. Byrne and Davis $(2002,2003)$ reach a similar conclusion, though they used fewer countries and indices, and compared one index at a time.

Another important implication is that the variety in financial system structures is likely to remain a feature of economic landscape, and that convergence may not be as fast as casual observation and qualitative analyses may suggest. This is not necessarily bad, for, as we noted in section 2 and logic suggests, there may be a 
variety of efficient financial system structures that can support economic growth.

Nevertheless, it does suggest that legislation encouraging a common systemic norm, either bank-based or, more likely, capital-market-based systems, may be ineffective or misguided. Consider, for example, the case of France. Quoting from Allen and Gale (2001, p.6)

"As one contemplates the panoply of measures that took effect in France from late 1984 to the end of 1986 , there is no doubt that the changes were inspired by a general vision. This was no mere lifting of controls: new instruments were created; new markets were added, including markets in futures; and the importance of permitting every individual agent to hedge his risks was clearly recognized."

Yet, as our analysis shows, France is still in the 'middle group' in terms of development of all segments of the financial system in the first cluster analysis. In addition, she is not among the countries with the more pronounced changes in the capital-markets segment in the second analysis.

Consider, next, the new framework for bank regulation, the so-called Basle II. Its Third Pillar relies on market discipline and, essentially, on the functioning of well-developed and efficient capital markets. Given, however, the findings of this paper, which cast doubt on the convergence of financial systems towards the capital-market-based norm, this Pillar may not function as envisaged, thus potentially jeopardizing Basle II's effectiveness at least in some countries.

It seems, therefore, that it is precarious to over-simplify. In addition, what we do not see in financial system structure and their changes is, to some extend, more interesting than what we do see. In France for example, we do not see in the indices used the impact of the targeted financial regulation revolution of the mid 1980s. Nor do we see the impact of Japan's in the 1990s.

Closing, this paper is not the first to argue that the reality of financial system structure is a lot more complex than suggested by the theoretical paradigms. Yet, its analysis is more comprehensive and robust than the few existing ones. As such, we expect that it will be the springboard of further thinking about the systemic changes of capital-market-based and bank-based financial systems, and about financial system regulation.

\section{Acknowledgements}

We gratefully acknowledge many helpful comments on the technicalities of 
cluster analysis by Markos Koutras, and on the contents of the paper by Nikitas Pittis, Nicholas Apergis and seminar participants at the $63^{\text {rd }}$ International Atlantic Economic Conference, Madrid, March 2007 and the $11^{\text {th }}$ International Conference on Macroeconomic Analysis and International Finance, Crete, May 2007. The usual disclaimer applies.

\section{References}

Allen, F. and Gale, D. (2001), Comparing Financial Systems, MIT Press, Cambridge, MA.

Allen, F. and Santomero, A. (2001), "What Do Financial Intermediaries Do?", Journal of Banking and Finance, 25(2): 271-294.

Beck, T., Demirgüç-Kunt, A. and Levine, R. (2000), "A New Database on Financial Development and Structure", World Bank Economic Review 14: 597-605.

Byrne, J.P. and Davis, P.E. (2002), "A Comparison of Balance Sheet Structures in Major EU Countries", National Institute Economic Review 180: 83-95.

Byrne, J.P. and Davis, P.E. (2003), Financial Structure: An Investigation of Sectoral Balance Sheets in the G-7, Cambridge University Press.

Edey, M. and Hviding, K. (1995), "An Assessment of Financial Reform in OECD Countries", Organization for Economic Co-operation and Development, Working Paper No 154.

Fohlin, C. M. (2000), "Economic, Political, and Legal Factors in Financial System Development: International Patterns in Historical Perspective", Social Science Working Paper No. 1089.

Kaufman, L. and Rousseeuw P. J. (1990), "Finding Groups in Data: an Introduction to Cluster Analysis", New York: John Wiley and Sons, Inc.

La Porta, R., Lopez-de-Silanes, F., Shleifer, A. and Vishny, R.W. (1997), "Legal Determinants of External Finance", Journal of Finance LII (3): 1131-1150. (1998), "Law and Finance", Journal of Political Economy 106(6): 1113-1155. (2002), "Investor Protection and Corporate Valuation", Journal of Finance LVII (3): 1147-1170.

La Porta, R., Lopez-de-Silanes, F., and Shleifer, A.(1999), "Corporate Ownership around the World", Journal of Finance LIV (2): 471-517.

Mishkin, F. and Strahan, P. (1999), "What Will Technology Do to Financial Structure", NBER Working Paper No. 6892.

Rajan, R. and Zingales, L. (2003), "Banks and Markets: the Changing Character of European Finance”, NBER Working Paper No. 9595.

SPSS 13.0 Base User's Guide.

Williamson, J. and Mahar, M. (1998), "A Survey of Financial Liberalization”, Princeton Essays in International Finance No. 211. 